\title{
PENGARUH MANAJEMEN KELAS TERHADAP MINAT BELAJAR SISWA KELAS XII IPA V SMA DARUSSALAM BLOKAGUNG TEGALSARI BANYUWANGI TAHUN PEMBELAJARAN 2020/2021
}

\author{
Nurkafid Nizam Fahmi ${ }^{1}$, Hasan Abdul Wafi ${ }^{2}$ \\ e-mail: fahminizam26@gmail.com ${ }^{1}$, maswafiterate@gmail.com ${ }^{2}$ \\ Prodi Manajemen Pendidikan Islam \\ Institut Agama Islam Darussalam Blokagung Banyuwangi
}

\begin{abstract}
Abstrak
Pendidikan memiliki peran yang penting dalam suatu negara. Melalui pendidikan yang bermutu suatu negara bisa menatap masa depannya. Dalam penelitian ini difokuskan pada manajemen kelas, minat belajar di SMA Darussalam Blokagung Tegalsari Banyuwangi, terkait hal tersebut, penulis berusaha menjawab dua pertanyaan pokok, yaitu: (1) Adakah pengaruh Manajemen Kelas Terhadap Minat Belajar Siswa Kelas X1I IPA V SMA Darussalam Blokagung Tegalsari Banyuwangi Tahun Pembelajaran 2019/2020 (2) Seberapa besar Pengaruh Manajemen Kelas Terhadap Minat Belajar Siswa Kelas X1I IPA V SMA Darussalam Blokagung Tegalsari Banyuwangi Tahun Pembelajaran 2019/2020. Penelitian ini menggunakan metode deskriptif kuantitatif dengan teknik analisis regresi linear sederhana. Populasi penelitian adalah sejumlah peserta didik di SMA Darussalam Blokagung Tegalsari Banyuwangi. Untuk mengukur variabel, peneliti menggunakan observasi, angket dan dokumentasi. Dalam menguji validitas instrument, peneliti menggunakan rumusan analisis regresi linier sederhana. Setelah melakukan analisis data yang dikumpulkan, ditemukan bahwa (1) ada pengaruh Manajemen Kelas Terhadap Minat Belajar Siswa Kelas X1I IPA V SMA Darussalam, (2) pengaruh Manajemen Kelas Terhadap Minat Belajar Siswa Kelas X1I IPA V SMA Darussalam Blokagung Tegalsari Banyuwangi adalah kuat dengan nilai 97,2\% dan sisanya 2,8 \% dipengaruhi oleh variabel lain.
\end{abstract}

Kata kunci: Manajemen Kelas, Minat Belajar

\section{Abstract}

Education has an important role in a country. Through quality education a country can look to its future. In this study focused on classroom management, interest in learning at the Darussalam High School in Tegalsari Banyuwangi Blockagung, related to this,

Pengaruh Manajemen Kelas Terhadap Minat Belajar Siswa Kelas XII IPA V SMA Darussalam Blokagung Tegalsari Banyuwangi Tahun Pembelajaran 2020/2021

Nurkafid Nizam Fahmi, Hasan Abdul Wafi 
the author tried to answer two main questions, namely: (1) Is there an influence of Class Management on Student Interest in Class X1I IPA V SMA Darussalam Blokagung Tegalsari Banyuwangi Year 2019/2020 Learning (2) How big is the Effect of Class Management on the Learning Interest of Class X1I Science V students in SMA Darussalam Blokagung Tegalsari Banyuwangi 2019/2020 Learning Year. This study uses quantitative descriptive methods with simple linear regression analysis techniques. The study population was a number of students in the Darussalam High School Blokagung Tegalsari Banyuwangi. To measure variables, researchers used observations, questionnaires and documentation. In testing the validity of the instrument, researchers used a simple linear regression analysis formula.After analyzing the data collected, it was found that (1) there was an effect of Class Management on the Learning Interest of Class X1I Science V SMA SMA Darussalam. (2) the effect of Class Management on Student Interest in Class X1I Natural Sciences V of SMA Darussalam BlokagungTegalsariBanyuwangi is strong with a value of 97,2\% and the remaining 2,8\% is influenced by other variables.

Keywords: Class Management, Learning Interest

\section{A. Pendahuluan}

Pendidikan merupakan salah satu aspek kehidupan manusia yang sangat penting, adapun wujud dari pendidikan adalah belajar, karena belajar merupakan upaya dalam memperoleh ilmu pengetahuan. Pendidikan itu sendiri menyatakan bahwa setiap muslim wajib melakukan kegiatan belajar merupakan kegiatan yang paling penting, karen berhasil tidaknya pencapaian suatu tujuan pendidikan bergantung kepada kegiatan belajar yang dialami oleh siswa. Di dalam UndangUndang Republik Indonesia Nomor 20 Tahun 2003 tentang Sistem Pendidikan Nasional menyebutkan bahwa, "pendidikan merupakan usaha sadar dan terencana untuk mewujudkan suasana belajar dan proses pembelajaran agar peserta didik secara aktif mengembangkan potensi dirinya untuk memiliki kekuatan spiritual keagamaan, pengendalian diri, kepribadian, kecerdasan, akhlak mulia, serta keterampilan yang dibutuhkan dirinya, masyarakat dan bangsa”.

Menurut Djamarah dan Zain (2010:173) bahwa "Manajemen kelas merupakan keterampilan guru untuk menciptakan dan memelihara kondisi belajar yang optimal dan mengembalikan bila terjadi gangguan dalam proses 
belajarmengajar". Di antara masalah yang ditemukan oleh peneliti adalah sebagai berikut, kurangnya minat belajar siswa pada saat proses belajar mengajar berlangsung, kurang adanya perhatian khusus terhadap minat belajar siswa, oleh karena itu manajemen kelas sangat diperlukan karena hari demi hari dan waktu kewaktu tingkah laku danperbuatan siswa selalu berubah.

Kurangnya kesadaran pendidik dalam memanajemen kelas mengakibatkan menurunnya minat belajar peserta didik pada saat proses belajar mengajar berlangsung, seperti metode mengajar yang digunakan tidak disenangi siswa, pemberian tugas rumah yang terlalu banyak kepada siswa, guru tidak tepat waktu dalam masuk kelas, masih ada pendidik yang tidak masuk kelas pada jam mengajarnya, dan kurang tepat waktu dalam melakukan proses belajar mengajar. Menurut undang undang RI nomor 14 tahun 2005 pasal 1 "guru adalah pendidik profesional dengan tugas utama yaitu mendidik, mengajar, membimbing, mengarahkan, melatih, menilai dan mengevaluasi peserta didik pada pendidikan usia dini jalur pendidikan formal, dan pendidikan menengah". Guru yang profesional ialah guru yang bisa menerapkan metode mengajar yang baik sehingga proses belajar mengajar menjadi lebih berkualitas dan berpengaruh positif terhadap perkembangan peserta didik. Manajemen kelas yang baik memungkinkan sang guru mengajar dengan baik, karena kelas yang terhindar dari konflik yang memungkinkan guru mengembangkan apa-apa yang diinginkannya. Berbagai inovasi dilakukan untuk menciptakan iklim belajar yang baik, yang dapat memotivasi siswa untuk belajar lebih giat, berbagai strategi pembelajaran pun diterapkan. Manajemen kelas merupakan salah satu kegiatan yang dapat menciptakan iklim belajar tersebut. Salah satu masalah yang sering terjadi dibeberapa sekolah mulai dari tingkat sekolah dasar sampai sekolah menengah yaitu persoalan-persoalan pada peserta didik dalam menerima materi pelajaran yang disampaikan oleh pendidik.

Tujuan penelitian ini adalah: 
1. Untuk mengetahui ada tidaknya pengaruh manajemen kelas terhadap minat belajar siswa di kelas XII IPA V SMA Darussalam Blokagung Tegalsari Banyuwangi Tahun Pembelajaran 2019/2020

2. Untuk mengetahui Seberapa besar pengaruh antara manajemen kelas terhadap minat belajar siswa di kelas XII IPA V SMA Darussalam Blokagung Tegalsari Banyuwangi Tahun Pembelajaran 2019/2020

\section{B. Metode Penelitian}

1. Jenis Penelitian

Jenis penelitian yang digunakan dalam penelitian ini adalah jenis deskriptif kuantitatif yaitu penelitian yang bertujuan untuk menguraikan atau menggambarkan tentang sifat-sifat dari suatu keadaan atau objek penelitian, dengan menggunakan data yang bersifat numerik atau angka. Hal ini selaras dengan pendapat Sugiyono (2015: 13) bahwa, "disebut metode kuantitatif karena data penelitiannya berupa angka-angka dan analisisnya menggunakan statistik".

2. Populasi dan Sampel

Populasi adalah keseluruhan subyek yang akan diteliti dan diukur. Sesuai dengan pendapat Sugiyono (2018: 130) bahwa, "populasi adalah keseluruhan subyek yang akan diukur dan merupakan unit yang diteliti”. Dalam penelitian ini populasinya ialah semua siswa kelas XII IPA V yang berjumlah 32 siswa yang menjadi objek perhatian peneliti yang memiliki karakteristik yang hendak diduga. Adapun yang menjadi populasi dalam penelitian ini adalah Siswa kelas XII IPA V SMA Darussalam Blokagung Tegalsari Banyuwangi Tahun Pembelajaran 2019/2020 yang berjumlah 32 siswa.

Menurut Sugiyono (2008: 81) mendeskripsikan bahwa, "sampel adalah bagian dari jumlah dan karakteristik yang dimiliki oleh populasi peneliti tidak menggunakan sampel. Hal ini sesuai dengan pendapat Arikunto (2006: 
134), "Apabila subyeknya kurang dari 100, maka lebih baik diambil semua sehingga penelitiannya merupakan penelitian populasi" karena subyeknya kurang dari 100 berdasarkan pendapat tersebut maka dalam penelitian ini yang diteliti semua subyek yang ada.

3. Instrumen penelitian

Instrumen yang digunakan untuk penelitian ini berupa angket dan dokumentasi. Angket dalam penelitian ini berupa pertanyaan-pertanyaan mengenai manajemen kelas terhadap minat belajar siswa di SMA Darussalam. Sesuai pendapat Sugiono (2015: 119) bahwa instrumen penelitian adalah alat atau fasilitas yang digunakan oleh peneliti untuk mengumpulkan data agar berjalan dengan mudah dan hasil yang lebih baik.

4. Uji validitas dan reliabilitas

a. Validitas data

Sebuah instrumen dikatakan valid apabila mampu mengukur apa yang diinginkan, dengan kata lain dapat mengungkap data dari variabel yang diteliti secara tepat. Sesuai pendapat arikunto (1998: 160), bahwa "validitas adalah suatu ukuran yang.menunjukkan tingkat tingkat kevalidan suatu instrumen".Dalam kuesioner penelitian, menggunakan butir validitas instrumen, dikatakan validitas jika mempunyai dukungan yang besar terhadap total skor. Untuk mengukur validitas, menggunakan rumus korelasi pearson product moment.

b. Reliabilitas data

Reabilitas menunjukkan tingkat konsistensi dan akurasi hasil pengukuran. Reabilitas data menurut pendapat Arikunto (1998: 170) bahwa,"instrumen cukup dapat dipercaya untuk digunakan sbagai alat pengumpul data karena instrumen tersebut sudah baik".Sebuah instrumen dapat dikatakan reliabel apabila instrumen tersebut digunakan untuk mengukur objek yang sama lebih dari satu kali akan diperoleh hasil 
pengukuran yang sama. Pengujian reliabilitas dilakukan dengan menggunakan teknik Cronbach alpha > 0,6.selanjutnya pengujian reabilitas instrumen dengan menggunakan rumus Alpha cronbach's karena instrumen penelitian ini berbentuk angket. Selanjutnya rumus ini juga digunakan untuk mencari reabilitas instrumen yang skornya bukan satu dan nol, misalnya angket atau soal bentuk uraian.

5. Teknik Pengumpulan Data

Teknik pengumpulan data yang digunakan dalam penelitian berupa observasi, angket dan dokumentasi.

Untuk lebih jelasnya diuraikan sebagai berikut:

a. Observasi

Teknik pengumpulan data ini digunakan untuk menjaring data yang diperlukan guna melengkapi data dari wawancara. Menurut Sutopo (dalam Harsono, 2008: 164), observasi merupakan kegiatan pengamatan yang dilakukan oleh peneliti di mana peneliti berperan aktif dalam lokasi studi sehingga benar- benar terlihat dalam kegiatan yang ditelitinya.

Dalam hal ini observasi difokuskan pada hal-hal yang berhubungan dengan variable indikator yang telah ditentukan, yaitu manajemen kelas dan minat belajar.

b. Angket

Angket adalah seperangkat pertanyaan atau pernyataan yang harus dijawab atau dilengkapi oleh responden. Setiap variable indikator diwakili oleh beberapa item angket yang diharapkan mendapat angket yang valid dan reliable yang mewakili masing-masing variabel indikator.

Dalam angket terdapat 10 butir instrumen dari variabel manajemen kelas kelas dan terdapat 10 butir instrumen dari variabel minat belajar, sehingga jumlah dari seluruh instrumen adalah 20 butir pernyataan.

c. Dokumentasi 
Dokumentasi adalah pengambilan data yang diproses melalui dokumen-dokumen. Metode dokumentasi dipakai untuk mengumpulkan data dari sumber-sumber dokumen yang mungkin mendukung. Teknik ini dilakukan untuk memperoleh data yang berupa dokumen atau arsip. Metode dokumentasi dilaksanakan untuk melengkapi data yang diperoleh dari wawancara dan observasi. Data yang diperoleh berupa tulisan, rekaman, seperti buku-buku pedoman, laporan resmi, catatan harian, notulen rapat (Arikunto, 2002: 135). Dalam penelitian ini, teknik dokumentasi dilakukan dengan cara mengumpulkan dokumen-dokumen resmi yang berhubungan dengan manajemen kelas di SMA Darussalam.

6. Teknik Analisis Data

Dalam penelitian ini teknik data analisis dengan menggunakan regresi linear sederhana. Regresi linear sederhana bertujuan untuk mengestimasi nilai variabel minat belajar siswa atau dependen (Y) dari independen yaitu manajemen kelas $(\mathrm{X})$. Untuk analisis regresi linear sederhana menggunakan bantuan program SPSS. Persamaan regresi linear sederhana dengan rumus sebagai berikut:

Persamaan regresi linear sederhana dengan rumus sebagai berikut:

$$
Y^{\prime}=a+b X
$$

Keterangan :

$\mathrm{Y}^{\prime}=$ subyek dalam variabel bebas (independent variable) yang diprediksikan

$\mathrm{a}=$ harga $\mathrm{Y}$ bila $\mathrm{X}=0$ (harga konstan)

$\mathrm{b}=$ koefisien regresi yang menunjukkan angka penimgkatan atau penurunan variabel tergantung (dependent variabel)

$\mathrm{X}=$ subjek pada variabel bebas (independent variabel) yang mempunyai nilai tertentu

Dimana, 


$$
\text { Harga } \mathrm{b}=r \frac{\delta y}{\delta x}
$$

Keterangan:

$\mathrm{r} \quad=$ Koefisien product moment antara variabel $\mathrm{X}$ dengan variabel

Y

Sy = Simpangan baku variabel Y

$\mathrm{Sx} \quad=$ Simpangan baku variabel $\mathrm{X}$

Harga B merupakan fungsi koefisien korelasi. Bila koefisien korelasi tinggi, maka B juga besar, sebaliknya bila koefisien rendah maka B juga rendah (kecil). Selain itu bila koefisien negatif maka harga B juga negatif, sebaliknya bila koefisien korelasi positif maka harga B juga positif

\section{Hasil dan Pembahasan}

\section{Uji validitas, reabilitas dan normalitas}

Tabel 1. Hasil Uji Validitas Variabel Manajemen Kelas (X)

\begin{tabular}{|c|c|c|c|}
\hline No item & r-hitung & r-tabel & Keputusan \\
\hline 1 & 0,659 & $>0,34$ & Valid \\
\hline 2 & 0,605 & $>0,34$ & Valid \\
\hline 3 & 0,578 & $>0,34$ & Valid \\
\hline 4 & 0,407 & $>0,34$ & Valid \\
\hline 5 & 0,591 & $>0,34$ & Valid \\
\hline 6 & 0,573 & $>0,34$ & Valid \\
\hline 7 & 0,619 & $>0,34$ & Valid \\
\hline 8 & 0,576 & $>0,34$ & Valid \\
\hline 9 & 0,594 & $>0,34$ & Valid \\
\hline 10 & 0,396 & $>0,34$ & Valid \\
\hline
\end{tabular}

Sumber: Olahan peneliti, 2020

Tabel 2. Hasil Uji Validitas Variabel Minat Belajar (Y)

\begin{tabular}{|l|l|l|l|}
\hline No item & r-hitung & r-tabel & Keputusan \\
\hline
\end{tabular}


Vol. 3, No. 1: 143-156, April 2021

ISSN: 2722-7146 (Media Online)

\begin{tabular}{|c|c|c|c|}
\hline 1 & 0,622 & $>0,34$ & Valid \\
\hline 2 & 0,559 & $>0,34$ & Valid \\
\hline 3 & 0,553 & $>0,34$ & Valid \\
\hline 4 & 0,382 & $>0,34$ & Valid \\
\hline 5 & 0,614 & $>0,34$ & Valid \\
\hline 6 & 0,535 & $>0,34$ & Valid \\
\hline 7 & 0,637 & $>0,34$ & Valid \\
\hline 8 & 0,613 & $>0,34$ & Valid \\
\hline 9 & 0,595 & $>0,34$ & Valid \\
\hline 10 & 0,461 & $>0,34$ & Valid \\
\hline
\end{tabular}

Sumber: Olahan peneliti, 2020

Berdasarkan data validitas di atas, dapat dilihat bahwa pengujian pada instrumen variabel $\mathrm{X}$ dan $\mathrm{Y}$ adalah valid. Hal tersebut dapat dibuktikan menggunakan bandingan $\mathrm{r}$ tabel dengan taraf signifikan 0,05 dan dk 32-2=30 adalah 0,34. Dengan demikian butir pertanyaan dalam instrumen tersebut dapat dipercaya untuk mengumpulkan data yang diperlukan.

Sedangkan untuk mengetahui hasil pengukuran instrumen maka diperlukan uji reabilitas dengan menggunakan Alpha-Cronbach dengan hasil

Tabel 3. Hasil Reliabilitas Data

\begin{tabular}{|c|c|c|c|}
\hline No & Variabel & Cronbach Alpha & Kriteria \\
\hline 1 & Manajemen Kelas & 0,754 & Reliabel \\
\hline 2 & Minat belajar & 0,742 & Reliabel \\
\hline
\end{tabular}

Sumber: Olahan peneliti, 2020

Berdasarkan Tabel 3, dapat dilihat hasil reliabilitas variabel $\mathrm{X}$ dan $\mathrm{Y}$. Dari tabel tersebut menunjukkan bahwa Cronbach Alpha > 0,60 yang berarti reliabel. Dengan demikian, alat ukur yang digunakan dalam peneltian ini bersifat reliabel.

Untuk menguji apakah sampel yang digunakan mempunyai distribusi normal atautidak maka dibutuhkan uji normalitas dengan hasil: 
Tabel 4. Hasil Uji Normalitas

\begin{tabular}{|ll|r|r|}
\hline & & $\begin{array}{c}\text { rank } \\
\text { manajemenkel } \\
\text { as }\end{array}$ & $\begin{array}{c}\text { rank } \\
\text { motivasibe } \\
\text { lajar }\end{array}$ \\
\hline Spearman's rho & rank manajemenkelas & Correlation Coefficient \\
& Sig. (2-tailed) & 1.000 & $.978^{* *}$ \\
& $\mathrm{~N}$ &. & .000 \\
& rank minatbelajar $\quad$ Correlation Coefficient & 32 & 32 \\
& Sig. (2-tailed) & $.978^{* *}$ & 1.000 \\
& $\mathrm{~N}$ & .000 & 32 \\
\hline
\end{tabular}

Dari tabel di atas nilai sig. (2-tailed) $<0,05(0,000<0,05)$ maka H1 diterima dan $\mathrm{H} 0$ ditolak yang artinya signifikan.

\section{Analisis uji hipotesis}

Uji t digunakan untuk mengetahui apakah variabel $\mathrm{X}$ yaitu manajemen kelas dengan variabel Y yaitu minat belajar memiliki pengaruh signifikan atau tidak. Dalam menggunakan uji $\mathrm{t}$ dapat diambil kesimpulan dengan membandingkan antara thitung dan $t$ tabel dengan taraf signifikan 5\% atau 0,05. Berikut adalah keputusan hasil dari uji t:

Tabel 5. Hasil Uji T

\begin{tabular}{|ll|r|r|r|r|r|}
\hline \multirow{2}{*}{ Model } & \multicolumn{3}{|c|}{$\begin{array}{c}\text { Unstandardized } \\
\text { Coefficients }\end{array}$} & \multicolumn{1}{c|}{$\begin{array}{c}\text { Standardized } \\
\text { Coefficients }\end{array}$} & & \\
\cline { 2 - 6 } & \multicolumn{1}{|c|}{$\mathrm{B}$} & \multicolumn{1}{c|}{ Std. Error } & \multicolumn{1}{c|}{ Beta } & \multicolumn{1}{c|}{$\mathrm{t}$} & \multicolumn{1}{c|}{ Sig. } \\
\hline 1 & (Constant) & -.279 & 1.024 & & -.272 & .787 \\
& manajemenkelas & .998 & .031 & .986 & 31.980 & .000 \\
\hline
\end{tabular}

Sumber: olahan hasil SPSS

Dari tabel analisis uji $\mathrm{T}$ yang terdapat dalam tabel di atas, dapat diambil kesimpulan bahwa t hitung $>\mathrm{t}$ tabel, yaitu $31.980>1,697$. Dengan demikian, maka Ha diterima dan Ho ditolak. Dengan demikian maka manajemen kelas (X) memiliki pengaruh yang signifikan terhadap minat belajar (Y).Sedangkan untuk 
mengetahui pengaruh antara manajemen kelas dan minat belajar memiliki nilai yang signifikan atau tidak dibutuhkan uji F dengan hasil:

Tabel 6. Hasil Uji F

\begin{tabular}{|l|r|r|r|r|c|}
\hline Model & $\begin{array}{c}\text { Sum of } \\
\text { Squares }\end{array}$ & Df & $\begin{array}{c}\text { Mean } \\
\text { Square }\end{array}$ & F & Sig. \\
\hline 1 Regression & 927.754 & 1 & 927.754 & 1022.695 & $.000^{\mathrm{b}}$ \\
\hline
\end{tabular}

Dari Tabel 6 di atas, diketahui bahwa $\mathrm{F}$ hitung $>\mathrm{f}$ tabel dengan nilai $1022.695>2,53$ dengan arti bahwa Ho ditolak dan Ha diterima. Oleh karena itu, variabel X mempunyai pengaruh yang signifikan tehadap variabel. Kemudian untuk mengetahui seberapa besar pengaruh atau kontribusi yang diberikan oleh Xkepada Y secara simultan maka, bisa dilihat pada uji koefesien determinasi pada data summary. Varaibelmanasaja yang paling dominanpengaruhnya. Adapunpengaruh yang diberikanadalahsebagaiberikut:

Tabel 7. Model Summary

\begin{tabular}{|l|r|r|r|r|}
\hline \multicolumn{1}{l}{ Mode } & \multicolumn{1}{|c|}{$\mathrm{R}$} & $\mathrm{R}$ Square & $\begin{array}{c}\text { Adjusted R } \\
\text { Square }\end{array}$ & $\begin{array}{r}\text { Std. Error of } \\
\text { the Estimate }\end{array}$ \\
\hline 1 & $.986^{\mathrm{a}}$ & .972 & .971 & .95245 \\
\hline
\end{tabular}

a. Predictors: (Constant), manajemen kelas

b. Dependent Variable: minat belajar

Berdasarkan tabel di atas dapat diketahui $\mathrm{R}$ atau multiple sebesar 0,986 yang menunjukkan korelasi antara variabel bebas dengan variabel tergantung, karena dalam regresi linier sederhana terdapat dua variabel, maka korelasi antara manajemen kelas (X) terhadap minat belajar (Y) adalah sebesar 0,986. Besar R Square adalah 0,972 yang menunjukkan bahwa variabel religiusitas (X) mempengaruhi sebesar $97,2 \%$ terhadap minat belajar sedangkan sisanya sebesar 
2,8\% dipengaruhi oleh variabel lain yang tidak diteliti. Pembahasan pada penelitian ini adalah sebagai berikut:

1. Adakah pengaruh manajemen kelas terhadap minat belajar siswa di kelas XII IPA V SMA Darussalam Blokagung Tegalsari Banyuwangi Tahun Pembelajaran 2019/2020. Dalam latar belakang yang sudah dijelaskan dalam bab sebelumnya, terdapat dua rumusan masalah yang harus diselesaikan. Yang pertama terdapat pengaruh antara manajemen kelas dengan minat belajar siswa. Hal tersebut dapat dibuktikan dengan hasil uji F yang menunjukkan f hitung > f tabel dengan nilai $1022.695>2,53$ dibandingkan dengan $t$ tabel $\mathrm{N}=32-2=30$ dengan signifikansi $0,05=1,69$.

2. Seberapa besar pengaruh manajemen kelas terhadap minat belajar siswa di kelas XII IPA V SMA Darussalam Blokagung Tegalsari Banyuwangi Tahun Pembelajaran 2019/2020. Rumusan masalah yang kedua dapat dibuktikan dengan hasil R square yang menunjukkan nilai 0,972 dengan pengaruh sebesar 97,2\%. Dengan demikian dapat diambil kesimpulan bahwa variabel X yaitu manajemen kelas memiliki pengaruh 97,2\% terhadap variabel Y yaitu minat belajar. Untuk sisanya sebesar 2,8\% dipengaruhi oleh faktor lain. Pengaruh manajemen kelas terhadap minat belajar dapat digambarkan secara konseptuan sebagai berikut:

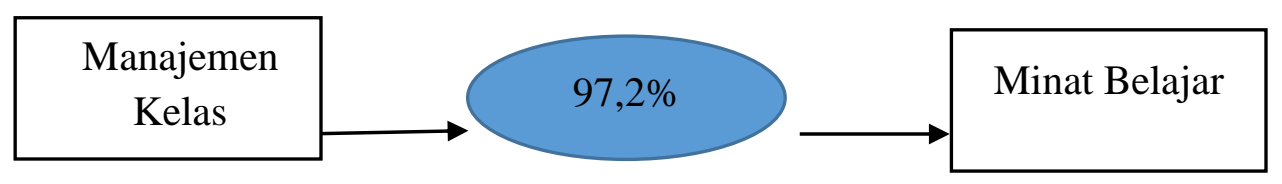

Gambar 1. Model Persamaan Regresi

\section{Kesimpulan}

Pengaruh Manajemen Kelas Terhadap Minat Belajar Siswa Kelas XII IPA V SMA Darussalam Blokagung Tegalsari Banyuwangi Tahun Pembelajaran 2020/2021 
Berdasarkan hasil uji $\mathrm{F}$ hitung yang menunjukkan nilai 1022.695 dengan bandingan $\mathrm{t}$ tabel $\mathrm{N}=32$ dan taraf signifikan 0,05=1,69 menghasilkan uji f hitung > $\mathrm{f}$ tabel, maka Ha diterima. Oleh karena itu, hasil penelitian menunjukkan bahwa ada pengaruh manajemen kelas terhadap minat belajar di SMA Darussalam.

Berdasarkan perhitungan yang dilakukan oleh peneliti dengan menggunakan rumus regresi linear sederhana, menunjukkan $\mathrm{t}$ hitung $=31.980$ dengan taraf signifikansi $0,000<0,05$ maka Ho ditolak. Dengan demikian diperoleh nilai signifikan dari hasil analisis regresi sebesar 0,972 dan jika dipersenkan menjadi 97,2\% Jadi, dapat disimpulkan bahwa manajemen kelas mempunyai pengaruh 97,2\% terhadap minat belajar. Sedangkan 2,8 \% di pengaruhi oleh faktor lain.

\section{E. Daftar Pustaka}

Arikunto, Suharsimi. 2006. Prosedur Penelitian suatu Pendekatan Praktik. Jakarta: Rineka Cipta

Depdikbud, 2001. Kamus Besar Bahasa Indonesia. Jakarta: Balai Pustaka

Djamarah Syaiful Bahri dan Zain Azwan. 2010. Strategi Belajar Mengajar. Jakarta:

\section{Rineka Cipta}

Nurhasanah Siti \& Sobandi. 2016. Minat Belajar Sebagai Determinan Hasil Belajar Siswa. Jurnal Pendidikan Manajemen Perkantoran, Vol. 1, hal. 137

Olivia Femi. 2007. Membantu Anak Punya Ingatan Super. Jakarta: PT Elex Media Komputindo, Cet. 1

Oviyanti Fitri. 2011. Teori Administrasi Pendidikan. Palembang: Rafa Press

Oviyanti Fitri. 2009. Pengelolaan Pengajaran. Palembang: Rafa Press

Saud Udin Syaefudin. 2011. Pengembangan Profesi Guru. Bandung: Alfabeta

Salman Rusydie. 2011. Prinsip-prinsip Manajemen Kelas. Bandung: PT. Remaja Rosdakarya 
Safari. 2003. Indikator Minat Belajar. Jakarta: Rineka Cipta

Syah Muhibbin. 2008. Psikologi Pendidikan dengan Pendekatan Baru, Bandung: PT. Remaja Rosdakarya

Sukmadinata Nana Syaodih. 2009. Landasan Psikologi Proses Pendidikan. Bandung: PT. Remaja Rosdakarya

Slamento, Belajar dan faktor-faktor yang mempengaruhi, (Jakarta: Rineka Cipta, 2010), hal. 180

Sugiono. 2015. Metode penelitian kuantitatif, kualitatif, dan R\&D. Bandung: Alfabeta

Suryabrata Sumadi. 2010. Psikologi Pendidikan. Jakarta: Rajawali Pers

Sutirman. 2013. Media dan Model-model Pembelajaran Inovatif. Yogyakarta:Graha Ilmu

Wiyani Novan Ardy. 2013. Manajemen Kelas: Teori dan Aplikasi untuk Menciptakan Kelas yang Kondusif. Yogyakarta: Ar-Ruzz Media

Wibowo Agus. 2013. Manajemen Pendidikan Karakter di Sekolah. Yogyakarta: Pustaka Pelajar 